\title{
Model Delone and Mclean untuk Mengukur Kesuksesan E-government Kota Pekalongan
}

\author{
Pujo Hari Saputro $^{1}$, A. Djoko Budiyanto ${ }^{2}$, Alb. Joko Santoso ${ }^{3}$ \\ ${ }^{1,2,3}$ Magister Teknik Informatika Universitas Atma Jaya Yogyakarta

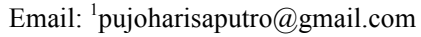

\begin{abstract}
Abstrak
Pemerintah Kota Pekalongan saat ini sudah menjadi salah satu kota percontohan dalam penggunaan E-government di Indonesia, banyak sistem sudah diterapkan dan berhasil membantu dalam pelayanan pemerintah kota kepada masyarakat dan juga mempermudah dalam pekerjaan pegawai pemerintahan. Metode DeLone and McLean yaitu metode yang mempunyai 6 variabel evaluasi yaitu: information quality, system quality, service quality, use, user satisfaction dan net benefit. Metode DeLone and McLean akan digunakan sebagai model mengukur kesuksesan $E$ government dalam penggunaannya untuk membantu kinerja pegawai pemerintahan kota pekalongan. Dengan model ini diharapkan dapat diketahui komponen-komponen yang mendukung atau menghambat dalam penggunaan E-government, sehingga ke depan diharapkan dapat menjadi bahan evaluasi untuk perbaikan.
\end{abstract}

Kata Kunci: Kota Pekalongan, Kesuksesan E-government, DeLone and McLean Models

\section{PENDAHULUAN}

Perkembangan Teknologi Informasi (TI) seperti E-government di dunia ini sudah sangat membantu dalam kehidupan sehari-hari, salah satu manfaat yang dapat dirasakan dan sudah membantu adalah memberikan sarana bagi pemerintah dalam mengelola pemerintahan dan juga membantu dalam hubungannya dengan masyarakat.

E-government di Indonesia saat ini sudah dapat digolongkan dalam golongan yang baik, dimana beberapa kota besar di Indonesia sudah mengaplikasikannya dan mampu membantu masyarakat dan juga kinerja pemerintahannya, salah satu kota yang sudah mengaplikasikan E-government adalah Kota Pekalongan. Kota Pekalongan sudah menjadi kota percontohan dalam penggunaan E-government selain itu prestasi yang lain adalah ditetapkannya Kota Pekalongan sebagai peringkat 1 PEGI (Pemeringkatan Egovernment) Kabupaten/Kota se-Jawa Tengah tahun 2011.

Sistem yang didukung Teknologi Informasi dapat memberikan nilai tambah bagi organisasi jika didesain menjadi sistem informasi yang efektif dan efisien. Namun demikian, pengukuran atau penilaian kualitas suatu sistem informasi yang efektif sulit dilakukan [1]. Kesulitan penilaian kesuksesan dan keefektifan sebuah sistem mendorong banyak peneliti mengembangkan model untuk menilai kesuksesan sebuah sistem. Penelitian serupa tentang pengukuran kesuksesan E-government dan juga sistem informasi sudah dilakukan sebelumnya oleh beberapa peneliti, seperti pada [2] yang memperoleh hasil bahwa penggunaan sistem informasi yang baik mampu memberikan dampak kepuasan pengguna dan juga berdampak positif pada organisasi, sedangkan menurut [3] pengaplikasian E-government mampu memangkas waktu yang digunakan. 
Selain itu peningkatan sistem menjadi sistem yang mempermudah pekerjaan user juga perlu dipertimbangkan untuk ditingkatkan. Artikel ini mengadopsi komponenkomponen yang ada pada model DeLone and McLean yaitu information quality, System quality, service quality, use, user satisfaction dan net benefit, untuk dijadikan model awal untuk mengukur sejauh mana kesuksesan implementasi E-government di Kota Pekalongan dalam mempermudah kinerja pegawai pemerintahan Kota Pekalongan dan faktor apa saja yang mempengaruhi kesuksesan dan kegagalannya agar dapat dievaluasi untuk pengembangan dan perbaikan selanjutnya.

Artikel ini bertujuan untuk membuktikan bahwa model DeLone and McLean dapat digunakan untuk menguji kesuksesan E-government Kota Pekalongan dan juga untuk membentuk usulan hipotesis dan juga usulan kuisioner yang diharapkan dapat digunakan sebagai acuan utuk penelitian-penelitian selanjutnya.

\section{METODE}

\subsection{Penelitian Terdahulu}

Penelitian tentang E-government pernah dilakukan sebelumnya, yaitu meneliti keberhasilan E-procurement kota Surabaya dengan menggunakan model DeLone and McLean, penelitian tersebut menghasilkan sebuah kesimpulan bahwa dari variabel yang didapatkan di DeLone and McLean mampu untuk menganalisa kesuksesan implementasi E-procurement kota Surabaya [3]. Selain itu, ada juga penelitian tentang kesuksesan implementasi salah satu sistem E-government pada RSUD Sragen dengan model DeLone and McLean, penelitian tersebut menganalisa bagaimana pengaruh implementasi sistem tersebut terhadap organisasi, dan faktor apa saja yang dapat mempengaruhi kesuksesan maupun kegagalan implementasi tersebut [11]. Penelitian serupa selanjutnya dilakukan untuk menguji kesuksesan SIMDA dengan model DeLone and McLean, tujuan dari penelitian yang dilakukan tersebut adalah untuk mengevaluasi apakah SIMDA tersebut sudah berhasil dan berdampak positif terhadap organisasi. Dalam penelitian tersebut juga berhasil dibuktikan bahwa hipotesis yang dibuat dari variabel yang ada pada model DeLone and Mclean mampu untuk mengukur keberhasilan implementasi sebuah sistem E-government [2].

Dari penelitian-penelitian tersebut memiliki beberapa aspek yang sama dengan penelitia ini, demografi yaitu penelitian-penelitian tersebut juga menggunakan pengguna langsung pada pemerintahan sebagai narasumber, aspek berikutnya adalah tentang tujuan penelitian yaitu untuk mengukur dan keberhasilan sistem E-government yang sudah diimplementasikan dan mencari faktor-faktor yang mempengaruhi kesuksesan dan kegagalannya.

\subsection{Model DeLone and McLean}

Beberapa model untuk mengukur tingkat kesuksesan sistem informasi telah dikembangkan oleh banyak peneliti $[4,5,6]$. Dari beberapa model kesuksesan sistem informasi, yang mendapat perhatian lebih dari para peneliti adalah model DeLone and McLean, yang selanjutnya disempurnakan menjadi Delone and Mclean Models yang menyebutkan bahwa information quality, system quality dan service quality akan 
berpengaruh positif pada use dan user satisfaction dan selanjutya akan berpengaruh positif pada net benefit atau hasil akhir [7,8], penelitian tersebut didukung pada penelitian yang dilakukan oleh J.Iivari yang menguji secara empiris model DeLone dan McLean tersebut, hasilnya membuktikan bahwa kesuksesan sistem informasi dipengaruhi oleh kualitas sistem informasi dan kualitas informasi yang dihasilkan dari sistem yang bersangkutan [9]. Model DeLone dan McLean ini ditunjukkan pada Gambar 1.

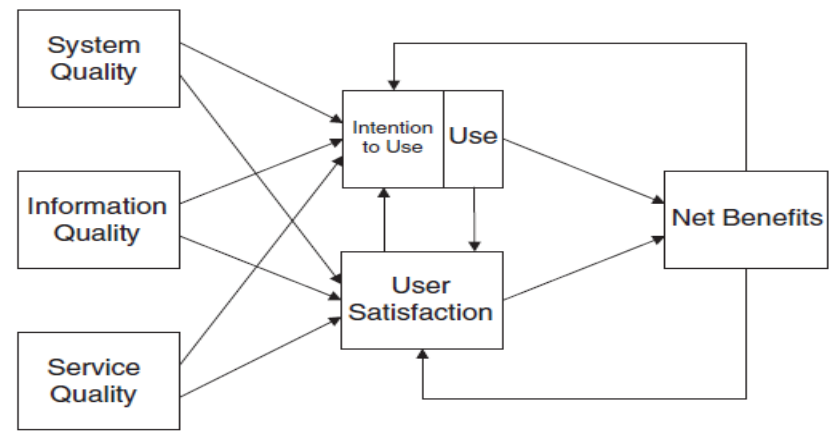

Gambar 1. Model DeLone and McLean [7]

Model ini dirasa cocok dan dapat digunakan sebab model DeLone and McLean tersebut juga sudah banyak digunakan sebelumnya oleh peneliti di Indonesia untuk mengukur kesuksesan sistem, seperti penelitian terdahulu [2], [3] dan [10], dimana dari model tersebut sebagai dasar hipotesis awal penelitian untuk menjadi acuan dalam pengembangan kuisioner untuk mengukur kesuksesan implementasi E-government.

\subsection{Hipotesis}

Dari model DeLone and McLean diatas diperoleh sebuah usulan hipotesis awal yaitu sebagai berikut:

H1a. Kualitas sistem (system quality) akan berpengaruh positif dan signifikan terhadap penggunaan (use);

H1b. Kualitas sistem (system quality) akan berpengaruh positif dan signifikan terhadap kepuasan pengguna (user satisfaction);

H2a. Kualitas informasi (information system) akan berpengaruh positif dan signifikan terhadap penggunaan sistem (use);

H2b. Kualitas informasi (information system) akan berpengaruh positif dan signifikan terhadap kepuasan pengguna (user satisfaction);

H3a. Kualitas pelayanan (service quality) akan berpengaruh positif dan signifikan terhadap penggunaan sistem (use);

H3b. Kualitas pelayanan (service quality) akan berpengaruh positif dan signifikan terhadap kepuasan pengguna (user satisfaction);

Kemudian jika kualitas sistem (system quality), kualitas informasi (information quality) dan pelayanan (service quality) sudah didapatkan, maka selanjutnya akan dilanjutkan 
dengan hipotesis yang akan mencari tahu apakah ada hubungan antara intention to use, user satisfaction dan net benefit.

H4a. Penggunaan sistem (use) akan berpengaruh positif dan signifikan terhadap kepuasan pengguna (user satisfaction), dan sebaliknya;

H4b. Penggunaan sistem (use) akan berpengaruh positif dan signifikan terhadap hasil bersih yang didapatkan (net benefit);

H5a. Kepuasan pengguna (user satisfaction) akan berpengaruh positif dan signifikan terhadap hasil bersih yang didapatkan (net benefit);

H6. Hasil bersih (net benefit) akan berpengaruh secara positif dan signifikan terhadap penggunaan sistem (use) dan kepuasan pengguna (user satisfaction).

\section{HASIL DAN PEMBAHASAN}

\subsection{Variabel dan Indikator}

Variabel yang digunakan disini adalah sesuai dengan usulan hipotesis dan juga yang ada pada model DeLone and McLean, selanjutnya dari variabel tersebut dicari indikator-indikator yang berpengaruh terhadap variabel tersebut, indikator yang didapat adalah indikator yang sudah dibuktikan oleh peneliti-peneliti terdahulu, untuk lebih lengkapnya sebagai berikut:

a. Kualitas Informasi (Information Quality)

Kualitas informasi mengukur kualitas keluaran dari sistem informasi [12]. Sama halnya dengan kualitas sistem, kualitas informasi yang dimaksud adalah kualitas informasi yang diukur secara subyektif oleh pemakai yang selanjutnya disebut sebagai kualitas informasi persepsi (perceived information quality). J.Iivari (2005) menggunakan enam skala pengukuran sebagai berikut: kelengkapan (completeness), ketepatan (precision), keandalan (reliability), data selalu diperbaharui (currency), dan bentuk dari keluaran (format of output) [9].

b. Kualitas Sistem (System Quality)

Kualitas sistem digunakan untuk mengukur kualitas informasi sistem itu sendiri, baik software maupun hardware. Kualitas sistem adalah performa dari sistem yang merujuk pada seberapa baik kemampuan perangkat keras, perangkat lunak, kebijakan, prosedur dari sistem informasi dapat menyediakan informasi kebutuhan pengguna [5].

Kualitas sistem diukur secara subyektif oleh pemakai, sehingga kualitas sistem yang digunakan adalah kualitas sistem persepsian (perceived system quality). Indikator yang digunakan mereplikasi dari penelitian J.Iivari (2005) terdiri atas 6 skala pengukuran yakni: fleksibilitas sistem (system flexibility), integrasi sistem (system integration), waktu respon (time to respon), perbaikan kesalahan (error recovery), kenyamanan akses (convinience of access), dan bahasa (language) [9].

c. Kualitas Layanan (Service Quality)

Kualitas layanan sebagai sebuah perbandingan dari harapan pelanggan dengan persepsi dari layanan nyata yang mereka terima. Menurut DeLone and McLean (2003) ada tiga komponen yang mempengaruhi dari kualitas layanan (service quality) yaitu jaminan (assurance) yaitu jaminan kualitas yang diberikan sistem, empati (system empathy) yaitu kepedulian sistem terhadap pengguna, system responsiveness yaitu kualitas respon sistem terhadap aksi yang dilakukan oleh pengguna [7]. 
d. Penggunaan (Use)

Dalam [12] dilakukan pembedaan penggunaan (use) ke dalam penggunaan keluaran (information use) dan penggunaan sistem (system use) yang berarti penggunaan informasi dan penggunaan dari sistem informasi itu sendiri. Dari pembedaan itu perlu mendapat perhatian, bahwa dalam konteks penggunaan sistem informasi Pemerintah Kota Pekalongan, penggunaan dimaksud adalah penggunaan aplikasi atau sistem informasi biling sistem itu sendiri (system use). Mereplikasi item yang digunakan pada penelitian J.Iivari (2005), artikel ini menggunakan dua item yaitu penggunaan waktu harian (daily used time) dan frekuensi penggunaan (frequency of use) yang dimaksud frekuensi penggunaan adalah frekuensi penggunaan sistem selama bekerja [9].

e. Kepuasan Pengguna (User Satisfaction)

Kepusasan pemakai sistem (user satisfaction) merupakan respon dan umpan balik yang dimunculkan pengguna setelah memakai sistem informasi. Sikap pengguna terhadap sistem informasi merupakan kriteria subjektif mengenai seberapa suka pengguna terhadap sistem yang digunakan. Mengadopsi dari DeLone and McLean (2003) artikel ini menggunakan dua item yaitu: [7]

1) Kepuasan Informasi (Repeat Purchase)

Perbedaan antara informasi yang dibutuhkan serta informasi yang diterima. "Secara umum kepuasan informasi sebagai hasil perbandingan pengharapan atau kebutuhan sistem informasi dengan kinerja sistem yang diterima".

2) Kepuasan Menyeluruh (Repeat Visit)

Salah satu bentuk kepuasan secara global atas semua sistem yang sudah disajikan dan dilakukan interaksi mengenai tingkat kepuasan layanan informasi dan sistem. Serta manfaat dalam dalam proses input proses output yang diterima.

f. Hasil bersih yang Didapat (Net Benefit)

Net benefit adalah hasil bersih atau keutungan yang dirasakan oleh individu dan juga organisasi setelah menerapkan sistem informasi. Artikel ini menggunakan lima dari enam item yang diadaptasi dari ukuran persepsi kegunaan (perceived usefulness) di [13] yakni: speed of acomplishing task, job performance, effectiveness, ease of job, dan usefullness in work.

\subsection{Penyusunan Kuisioner}

Dari variabel-variabel model DeLone and McLean, maka didapatkan usulan kuisioner yang disusun berdasarkan indikator-indikator yang didapatkan dari penelitian sebelumnya. Variabel information quality diwakili dengan (IQ), system quality (SQ), service quality (SEQ), use (U), user satisfaction (US), net benefit (NB). Komponen kuisioner dapat dilihat pada Tabel 1.

Tabel 1. Tabel kuisioner

\begin{tabular}{llllll}
\hline No & Komponen & Sumber & Indikator & \multicolumn{2}{c}{ Kuisioner } \\
\hline 1 & & & & Kode & \multicolumn{2}{c}{ Pertanyaan } \\
\hline & Information & J.Iivari & Completeness & IQ1 & $\begin{array}{l}\text { Saya mendapat data yang } \\
\text { lengkap sesuai kebutuhan } \\
\text { pekejaan! }\end{array}$ \\
\hline
\end{tabular}




\begin{tabular}{|c|c|c|c|c|c|}
\hline No & Komponen & Sumber & Indikator & & Kuisioner \\
\hline & & & & Kode & Pertanyaan \\
\hline \multirow{10}{*}{2} & \multirow{10}{*}{$\begin{array}{l}\text { System } \\
\text { Quality }\end{array}$} & \multirow{10}{*}{$\begin{array}{l}\text { J.Iivari } \\
(2005) \\
{[9]}\end{array}$} & Precision & IQ2 & $\begin{array}{l}\text { Informasi yang saya dapatkan } \\
\text { sesuai dengan data yang } \\
\text { sebenarnya! }\end{array}$ \\
\hline & & & Reability & IQ3 & $\begin{array}{l}\text { Saya dapat mengandalkan data } \\
\text { yang didapatkan dalam } \\
\text { memenuhi kebutuhan informasi } \\
\text { utuk bekerja! }\end{array}$ \\
\hline & & & Currency & IQ4 & $\begin{array}{l}\text { Data yang saya dapatkan adalah } \\
\text { informasi yang terkini dan } \\
\text { selalu diperbaharui! }\end{array}$ \\
\hline & & & Format of Output & IQ5 & $\begin{array}{l}\text { Data yang saya dapatkan dapat } \\
\text { saya gunakan di alat atau media } \\
\text { lain! }\end{array}$ \\
\hline & & & $\begin{array}{l}\text { System } \\
\text { Flexibility }\end{array}$ & SQ1 & $\begin{array}{l}\text { Saya dapat menggunakan } \\
\text { sistem dan merubah data yang } \\
\text { tersedia sesuai kebutuhan } \\
\text { pekerjaan! }\end{array}$ \\
\hline & & & $\begin{array}{l}\text { System } \\
\text { Integration }\end{array}$ & SQ2 & $\begin{array}{l}\text { Saya dapat berinteraksi dengan } \\
\text { sistem dan instansi yang lain } \\
\text { menggunakan sistem yang ada! }\end{array}$ \\
\hline & & & Time to Respond & SQ3 & $\begin{array}{l}\text { Saya tidak perlu waktu lama } \\
\text { mendapatkan informasi setelah } \\
\text { mengakses sistem! }\end{array}$ \\
\hline & & & Error Recovery & SQ4 & $\begin{array}{l}\text { Sistem memberikan fasilitas } \\
\text { perbaikan jika terjadi kegagalan } \\
\text { sistem! }\end{array}$ \\
\hline & & & $\begin{array}{l}\text { Convinience of } \\
\text { Access }\end{array}$ & SQ5 & $\begin{array}{l}\text { Saya merasa } \\
\text { mudah dalam } \\
\text { sistem! }\end{array}$ \\
\hline & & & Language & SQ6 & $\begin{array}{l}\text { Saya dapat dengan mudah } \\
\text { mengerti bahasa yang dimaksud } \\
\text { oleh sistem! }\end{array}$ \\
\hline \multirow[t]{3}{*}{3} & \multirow[t]{3}{*}{$\begin{array}{l}\text { Service } \\
\text { Quality }\end{array}$} & \multirow{3}{*}{$\begin{array}{l}\text { DeLone } \\
\text { and } \\
\text { McLean } \\
(2003)[7]\end{array}$} & Assurance & SEQ1 & $\begin{array}{l}\text { Saya merasa aman dalam } \\
\text { mengkses atau mengirim data } \\
\text { melalui sistem! }\end{array}$ \\
\hline & & & Empathy & SEQ2 & $\begin{array}{l}\text { Sistem memberikan beberapa } \\
\text { masukan yang mungkin } \\
\text { berguna bagi pekerjaan saya! }\end{array}$ \\
\hline & & & Responsiveness & SEQ3 & $\begin{array}{l}\text { Sistem memberikan tanggapan } \\
\text { sesuai dengan apa yang saya } \\
\text { laukan! }\end{array}$ \\
\hline \multirow[t]{2}{*}{4} & \multirow[t]{2}{*}{ Use } & \multirow{2}{*}{$\begin{array}{l}\text { J.Iivari } \\
(2005) \\
{[9]}\end{array}$} & Daily Used Time & $\mathrm{U} 1$ & $\begin{array}{l}\text { Dalam sehari saya mengakses } \\
\text { sistem! }\end{array}$ \\
\hline & & & $\begin{array}{l}\text { Frequency of } \\
\text { Use }\end{array}$ & $\mathrm{U} 2$ & $\begin{array}{l}\text { Selama bekerja di instansi, } \\
\text { frekuensi saya mengakses } \\
\text { sistem! }\end{array}$ \\
\hline \multirow[t]{2}{*}{5} & \multirow[t]{2}{*}{$\begin{array}{l}\text { User } \\
\text { Statisfaction }\end{array}$} & \multirow{5}{*}{$\begin{array}{l}\text { DeLone } \\
\text { and } \\
\text { McLean } \\
(2003)[7] \\
\text { Davis } \\
(1989) \\
{[13]}\end{array}$} & $\begin{array}{l}\text { Repeat } \\
\text { Purchases }\end{array}$ & US1 & $\begin{array}{l}\text { Saya puas dengan data dan } \\
\text { informasi yang saya dapat! }\end{array}$ \\
\hline & & & Repeat Visits & US2 & $\begin{array}{l}\text { Saya puas dengan sistem yang } \\
\text { ada! }\end{array}$ \\
\hline \multirow[t]{3}{*}{6} & Net Benefit & & $\begin{array}{l}\text { Speed of } \\
\text { acomplishing } \\
\text { task }\end{array}$ & NB1 & $\begin{array}{l}\text { Saya dapat menyelesaikan } \\
\text { pekerjaan lebih cepat dengan } \\
\text { menggunakan sistem! }\end{array}$ \\
\hline & & & Job performance & NB2 & $\begin{array}{l}\text { Kinerja saya lebih baik dengan } \\
\text { menggunakan sistem! }\end{array}$ \\
\hline & & & Effectiveness & NB3 & $\begin{array}{l}\text { Saya lebih efektif dalam bekerja } \\
\text { dengan menggunakan sistem! }\end{array}$ \\
\hline
\end{tabular}




\begin{tabular}{|c|c|c|c|c|c|}
\hline \multirow[t]{2}{*}{ No } & \multirow[t]{2}{*}{ Komponen } & \multirow[t]{2}{*}{ Sumber } & \multirow[t]{2}{*}{ Indikator } & \multicolumn{2}{|r|}{ Kuisioner } \\
\hline & & & & Kode & Pertanyaan \\
\hline & & & Ease of Job & NB4 & $\begin{array}{l}\text { Saya merasa lebih mudah dalam } \\
\text { bekerja dengan menggunakan } \\
\text { sistem! }\end{array}$ \\
\hline & & & $\begin{array}{l}\text { Usefullness in } \\
\text { Work }\end{array}$ & NB5 & $\begin{array}{l}\text { Sistem sangat berguna dalam } \\
\text { menyelesaikan pekerjaan dan } \\
\text { kegiatan organisasi! }\end{array}$ \\
\hline
\end{tabular}

\section{SIMPULAN}

Dari pembahasan yang dijelaskan maka didapatkan kesimpulan bahwa model DeLone and McLean dapat digunakan untuk mengukur kesuksesan E-government pada pemerintahan Kota Pekalongan. Selain itu, didapatkan sebuah usulan kuisioner yang disusun dengan mengadaptasi variabel yang ada pada model DeLone and McLean, yang selanjutnya diharapkan mampu digunakan untuk mengevaluasi kinerja E-government Pemerintah Kota Pekalongan. Selanjutnya dapat diketahui faktor-faktor yang mempengaruhi kesuksesan dan kegagalan implementasi E-government untuk dijadikan perbaikan selanjutnya.

\section{REFERENSI}

[1] Furukawa, M., Minami, A. 2013. A Study on the 'Flexibility' of Information Systems (Part 1): Why Do They Need to Be Flexible?. Int. J. Bus. Manag. Vol. 8(20): 48-61.

[2] Wahyuni, T. 2011. Uji Empiris Model Delone dan Mclean Terhadap Kesuksesan Sistem Informasi Manajemen Daerah (SIMDA). J. Badan Pendidik. dan Pelatih. Keuang. Vol. 2 (99).

[3] Pramadani, R.M., Mudjahidin. 2013. Analisis Keberhasilan E-procurement Pemerintah Kota Surabaya Menggunakan Information System Success Model. Jurnal Teknik POMITS. Vol. 1(1): 1-6.

[4] Bailey, J. E., Pearson, S. W., Science, S. M., and May, N. 1983. Development of a Tool for Measuring and Analyzing Computer User Satisfaction *. Manage. Sci. Vol. 29(5): 530-545.

[5] DeLone, W. H., McLean, E. R. 1992. Information Systems Success: The Quest for the Dependent Variable. Inf. Syst. Res., vol. 3, no. 4,:60-95.

[6] Seddon, P. B. 1997. A Respecification and Extension of the Delone and Mclean Models of IS success.

[7] DeLone, W. H., McLean, E. R. 2003. The DeLone and McLean Model of Information Systems Success: A Ten-Year Update. J. Manag. Inf. Syst. Vol. 19(4): 9-30.

[8] McGill, T., Hobbs, V., and Klobas, J. 2003. User Developed Applications and Information Systems Success: A Test of DeLone and McLean's model. Inf. Resour. Manag. J. Vol. 16 (1): 24-45.

[9] Iivari, J. 2005. An Empirical Test of the Model of Information System Success. DATA BASE Adv. Inf. Syst. Vol. 36(2): 8-27.

[10] Kerta, J. M. and Suryawan, A. D. 2013. Analysis Of information System Implementation in Binus University using Delone and Mclean Information System 
Success Model and Cobit Framework. International Journal of Communication \& Information Technology (CommIT). Vol. 7(1): 13-17.

[11] Budiyanto. 2009. Evaluasi Kesuksesan Sistem Informasi Dengan Pendekatan Model DeLone dan McLean (Studi Kasus Implementasi Billing System Di RSUD Kabupaten Sragen). Surakarta: Universitas Sebelas Maret. Tesis.

[12] Jogiyanto, H. 2007. Model Kesuksesan Sistem Teknologi Informasi. Andi Publisher, Yogyakarta.

[13] Davis, F. D. 1989. Perceived Ease of Use, and User Acceptance of Information Technology. MIS Q. Vol. 13(3): 319-340. 